\title{
Inspection of the imported food products and internally produced food products form the point of sanitation and quality
}

\author{
Mohammad Mehdi Moheghi \\ (Animal Science/Herat University, Afghanistan)
}

\begin{abstract}
This research had done on Export and Internal products which use by Afghan people. Tests on eggs showed that the internal eggs have better condition because of good weight, shell size, Albumin and yolk, and also there is no report of Salmonella. Tests on milk showed that the internal milk is good at high percentage of fat, Protein, Carbohydrates but there is always adulteration in these milks like adding water and starch. The research on water showed that there are hardness, $\mathrm{No}_{3}, \mathrm{No}_{2}, \mathrm{P}$, some kinds of Bacteria but no Arsenic in tap, well and mineral water.In meat test we had found that, both import frozen meat and daily slaughter had the same condition of total bacteria and Coliforms but the percentage was normal, with no Salmonella. Results showed that import apple had high Bricks in refract meter than Herati apple.Tests of sausage and tuna products of our country and the external samples had no coliforms but high percentage of total bacteria.
\end{abstract}

Keywords: Analysis, Eggs, Water, Meat, Milk, Sausage

\section{Introduction}

Afghanistan had passed too many years of war, after world union helps the situation of Afghanistan get better and the people started to think of rebuilding and production, but unfortunately the most important cities started to import the first necessary materials from other countries. There is no good quality control that it case some health problems. These may be case abuse of Afghanistan assets. The quality control of food products can help both internal and external products to have better human health. The important products in human feeding are consist of oil, rice, meat and... which are important because of quality and price.(Mitchell, 2004[1]) Whereas we know $80 \%$ of income in a family is use to get food materials, there must be economize of money and other harms in health. The Afghanistan companies are trying to get the highest level in production, the result of this research shows that government must be careful of import products and people must use the Afghan products. The important goal of this research is relationship of industry, people and university population. The relation of University and industry future voucher. This can make a better quality in teaching and practice field for students. We can show the result to people which they know all about food materials.

\section{Materials And Methods}

Eggs

Eggs had collected from both kinds of eggs from city and transfer them to Agriculture lab, Herat University. The most import eggs are from Iran and internal eggs produced in Herat that hopefully it has great improvement recently.

Procedure:

1- Collection of eggs Internal(Herati eggs) External eggs(Irani)

2- Eggs Quality Control, consist of these factors:

a) Average weight

b) Appearance quality of shape in size

c) Air sac size that shows oldness or freshness

d) High of Albumin (it has two parts which the first part is next to yolk and it must be higher than the second part doesn't a complete form.

e) Appearance of yolk ( if spread out easily it means the egg is so old)

f) Microbial culture of shell surface which shows existence of Salmonella Spp. For these propose we used two kinds of media:

- Tetrathionate Broth Base

- XLT4 agar base

In first media which is broth salmonella will growth in $24 \mathrm{hr}$. of course the color of media doesn't change after $24 \mathrm{hr}$ and we can observe black colonies on second media.

The second media which is Agar gel of XLT4 after 24hr:

- Black colonies $=$ Positive

- Yellow colonies $=$ Negative 


\section{Export and import broiler quality control}

For investigation of internal and external chicken meat we collected internal meat that they are produced in Herat city in broiler chicken farms and also the USA freeze broiler importing in Herat.

We were observing these samples for:

1- Physical appearance

2- Total bacterial culture

3- Coliform test

4- Salmonella

5- Water activity

6- $\mathrm{PH}$

As we know E.coli and Salmonella are parts of The Entrobacteracea family they live as normal flora and may cause some digestive problems. Meat is a good food material to growing all kinds of bacteria, we decided to do these tests for observing all results.

What do we need?

1- XLT4 agar base

2- VRBA

3- APC agar

4- Blander

5- $\mathrm{PBs}$

6- Dw

7- Heater

8- Autoclave

9- Incubator

10- $\mathrm{Ph}$ meter

11- Plates

12- Micotubes

13- Micropipates

PH test:

10 grams of samples

$90 \mathrm{ml}$ of Dw

We blundered samples with Dw then measured ph with ph meter.

\section{Water activity:}

10 gr of samples

Balance

Balance 10 grams of sample and write it down in a paper, then transfer it to refrigerator and hang it for $24 \mathrm{hr}$. after overnight we balance it again to observe how much water did it lose?(Kirklandet al, 2008[2])

APC test:

APC agar

Petri plates

PBS

Micotubes

Micropipates

Add 37 gr of APC agar to 1 lit of Dw and autoclave it for 121c for $15 \mathrm{~min}$. pur in plates and wait to get cold. We plated all samples for 4, 5, 6,7 dilutions. To make dilution balance $10 \mathrm{gr}$ of sample, bland it and mix with pbs in micotubes. The number of diluted samples are 1, 2, 3, 4, 5, 6, 7 but we only cultured 4, 5, 6, 7.( Albanese, 1976)

\section{Coliform test:}

Instate of APC we used VRBA (violet red bile agar)

VRBA is a media that grow coliforms and we could not autoclave it, just we heat it and wait for boiling, the procedure is the same as APC.

\section{Salmonella test:}

Instate of APC we used XLT4 agar base

The procedure is the same as APC.

We will send you all data with photo files (Bender, 1987[3])

Milk Analysis

For investigation of milk quality in Herat province and the import products from other countries like Iran and Pakistan we collected milk samples from different parts of city and some external products.

We studied these factors in the milk:

1- Slur measuring like adding water, oil, starch, etc...

2- $\mathrm{pH}$ meter 


\section{Adulteration measuring:}

Here are always some people who add some other material to milk for slurring but we can recognize them in different ways. We use Lactometer to read the real specific gravity in milk. Specific gravity in milk is from 1.028 - 1.030, the specific gravity of water is 1,00 , if someone add water to milk it will show a number near to 1 but if they add dry material like starch it will go high like 1.038. Here is another way to know if starch is present, just add some drops of Iodine if it get black it means there is starch in milk, in negative result it will show a yellow ring.

To measure $\mathrm{pH}$ we used $\mathrm{pH}$ meter. The $\mathrm{pH}$ should be between 6.5- 6.7

We had a milk analyzer machine that we record the all dry maters in milk such as:(Albanese, 1976[4])

1- Freezing point -0.512 to -0.550

2- Water $87 \%$

3- Total solids $\quad 13 \%$

4- Fat 4\%

5- Nonfat solids $\quad 9 \%$

6- Protein $\quad 3.5 \%$

7- Sugar $\quad 5.0 \%$

\section{Water Analysis}

To Comparison of drinking water in Herat and some mineral water companies we took samples and analyze these factors:

1- Hardness

2- $\mathrm{PH}$

3- Arsenic

4- Nitrate

5- Nitrite

6- Phosphate

7- Total bacteria

We need these equipment;

1- Autoclavable bottles

2- Autoclave

3- $\mathrm{pH}$ meter

4- Neogan filter

5- Media

Powders of Arsenic, Phosphate, Nitrate, Nitrite (Shiklomanov, 2000 [5])

Analysis of fresh fruit

For testing fresh fruit we need this materials:

1- Kinds of fruits like apple, Grape, pomegranate, Fig

2- Devices like refractometer and Penetrometer

\section{Procedure:}

1- With refractometer we know how much mineral and other substances are in fruit, because of this we chose a piece of fruit and press it for juice then we will see the blue color in reractometer that it show quantity of minerals in fruit.

For Penetrometer test we peel an area and with pressing we record the number in Penetrometer

Sausageand Tuna Analysis

For investigation of meat products quality in Herat bazars, we took some samples from both internal and external products. For investigation of number of total bacteria in sausage:

We need:

1- Sausage sample

2- PBS \& DW

3- VRBA media

4- Blander \& balance

5- Pippte

6- Plates

Procedure:

1- Balance 10 grs of sample

2- Blunder in DW

3- Dilute it in PBS(-1, -2, -3, -4,.., -10)

4- Culture in VRBA

5- Incubate for $24 \mathrm{hr}$

6- Recording data

We did all these procedures for tuna too. (Frazier, 1987[6]) 
Eggs results

\section{Results And Discussion}

Table 1. Weight, Albumin Height, and Shell Thick of Internal Industrial and ExternalIndustrial Eggs Available in Herat City, Afghanistan.

\begin{tabular}{|l|l|l|l|l|}
\hline Factors & Internal & External & SEM & P \\
\hline Weight, g & $61.99^{\mathrm{a}}$ & $53.58^{\mathrm{b}}$ & 0.58 & $<.0001$ \\
\hline Albumin, mm & $6.87^{\mathrm{a}}$ & $4.38^{\mathrm{b}}$ & 0.15 & $<.0001$ \\
\hline Shell Thick, mm & $0.42^{\mathrm{a}}$ & $0.37^{\mathrm{b}}$ & 0.004 & $<.0001$ \\
\hline
\end{tabular}

Table 2. Internal Quality Characteristics of Internal Industrial andExternal Industrial Eggs Available in Herat City, Afghanistan

\begin{tabular}{|l|l|l|l|l|}
\hline Factors & Internal & External & SEM & P \\
\hline Cracked Shells, \% & $2.00^{\mathrm{a}}$ & $2.4^{\mathrm{a}}$ & 0.42 & 0.5237 \\
\hline Yolk Color & $88.40^{\mathrm{a}}$ & $100.00^{\mathrm{b}}$ & 0.79 & $<.0001$ \\
\hline Yellow (\%) & $11.60^{\mathrm{a}}$ & $00.00^{\mathrm{b}}$ & 0.79 & $<.0001$ \\
\hline Orange (\%) & 00.00 & 00.00 & 00.00 & 00.00 \\
\hline Salmonella(\%) &
\end{tabular}

Numbers with different superscripts are significantly different at $\mathrm{P}<0.05$

According to the results in the appearance and quality of eggs. Eggs produced in Afghanistan in terms of all invoices is better than imported eggs Which goes back to being fresh eggs and locally made Afghanistan a shorter route that goes through the eggs to the consumer market(Food hygiene standards[7])

Export and import broiler quality control

Table 1.pH and Water activity of internal and external chicken meat

\begin{tabular}{|l|l|l|l|l|}
\hline Factors & Internal & External & SEM & $\mathrm{P}$ \\
\hline $\mathrm{pH}$ & $5.87^{\mathrm{b}}$ & $6.59^{\mathrm{a}}$ & 0.10 & 0.0083 \\
\hline Water activity & $2.16^{\mathrm{a}}$ & $2.42^{\mathrm{a}}$ & 0.15 & 0.2790 \\
\hline
\end{tabular}

Table 2. Percentage of chicken meat samples above the maximum contamination level

\begin{tabular}{|l|l|l|l|l|}
\hline Factors & Internal & External & SEM & P \\
\hline APC & $49.67^{\mathrm{a}}$ & $60.00^{\mathrm{b}}$ & 2.09 & 0.0252 \\
\hline Coliforms (\%) & $22.00^{\mathrm{a}}$ & $28.00^{\mathrm{a}}$ & 1.83 & 0.0808 \\
\hline Salmonella (\%) & 0.00 & 0.00 & 0.00 & 0.00 \\
\hline
\end{tabular}

Numbers with different superscripts are significantly different at $\mathrm{P}<0.05$

The results showed that chicken meat on the market Herat those who come from outside and those inside are produced in unsanitary conditions. This case relates to the lack of familiarity with the appropriate storage vendors meat and hygiene by vendors (Refrigeration and Food Safety, 2010 [8])

Milk Analysis

Table 1.Composition of milk samples collected from milk shops in Herat City, Afghanistan

\begin{tabular}{|l|l|l|l|l|l|l|l|}
\hline Source & $\begin{array}{l}\text { Protein } \\
(\%)\end{array}$ & Fat(\%) & Lactose(\%) & SNF(\%) & Salts(\%) & Freezing point & pH \\
\hline Locally Milk & $3.76^{\mathrm{a}}$ & $3.38^{\mathrm{a}}$ & $5.28^{\mathrm{a}}$ & $9.30^{\mathrm{a}}$ & $0.68^{\mathrm{a}}$ & $0.63^{\mathrm{a}}$ & $6.53^{\mathrm{b}}$ \\
\hline Iranian Milk & $3.67^{\mathrm{a}}$ & $2.86^{\mathrm{b}}$ & $5.17^{\mathrm{a}}$ & $9.06^{\mathrm{b}}$ & $0.61^{\mathrm{a}}$ & $0.57^{\mathrm{a}}$ & $6.51^{\mathrm{b}}$ \\
\hline Pakistani Milk & $2.58^{\mathrm{b}}$ & $2.53^{\mathrm{c}}$ & $3.59^{\mathrm{b}}$ & $9.20^{\mathrm{c}}$ & $0.45^{\mathrm{b}}$ & $0.34^{\mathrm{b}}$ & $6.96^{\mathrm{a}}$ \\
\hline SEM & 0.03 & 0.02 & 0.05 & 0.04 & 0.03 & 0.05 & 0.02 \\
\hline p & $<.0001$ & $<.0001$ & $<.0001$ & $<.0001$ & 0.0021 & 0.0222 & $<.0001$ \\
\hline
\end{tabular}

Numbers with different superscripts are significantly different at $\mathrm{P}<0.05$

Table 2.Percentage of milk samples with irregularities (fat, water and starch)

\begin{tabular}{|l|l|l|l|}
\hline & Starch & Fat & Water \\
\hline Locally Milk & $0.67^{\mathrm{a}}$ & $0.00^{\mathrm{a}}$ & $3.33^{\mathrm{a}}$ \\
\hline Iranian Milk & $0.00^{\mathrm{a}}$ & $0.00^{\mathrm{a}}$ & $0.00^{\mathrm{a}}$ \\
\hline Pakistani Milk & $0.00^{\mathrm{a}}$ & $0.00^{\mathrm{a}}$ & $100.00^{\mathrm{b}}$ \\
\hline SEM & 0.38 & 0.00 & 1.01 \\
\hline P & 0.4219 & 0.00 & $<.0001$ \\
\hline
\end{tabular}

The results showed that milk production in Afghanistan in terms of the amount of nutrients in a higher level of imported valves Due to lack of processing the milk that comes directly from the farm to the market. The results showed that milk production in some of the fraud, including the addition of water and starch milk can be seen 


\section{Water results}

Table 1. General Water Characteristic

\begin{tabular}{|l|l|l|}
\hline \multicolumn{2}{|l|}{} \\
\hline Source & $\mathrm{pH}$ & Total bacteria (\%) \\
\hline Mineral Water & $7.83^{\mathrm{b}}$ & $0.00^{\mathrm{a}}$ \\
\hline Tap Water & $7.62^{\mathrm{b}}$ & $1.33^{\mathrm{b}}$ \\
\hline Boiling Water & $8.50^{\mathrm{a}}$ & $0.00^{\mathrm{a}}$ \\
\hline Well Water & $7.77^{\mathrm{b}}$ & $2.33^{\mathrm{c}}$ \\
\hline SEM & & \\
\hline P & 0.13 & 0.75 \\
\hline Numbers with different superscripts are significantly different at $\mathrm{P}<0.05$ \\
\hline
\end{tabular}

Table 2.Percentage of water samples above the maximum contamination level

\begin{tabular}{|l|l|l|l|l|}
\hline source & Nitrite(NO2) & Nitrate(NO3) & Phosphate & Arsenic \\
\hline Mineral Water & $0.00^{\mathrm{a}}$ & $0.00^{\mathrm{a}}$ & $1.67^{\mathrm{a}}$ & 0 \\
\hline Tap Water & $2.67^{\mathrm{b}}$ & $10.33^{\mathrm{b}}$ & $7.33^{\mathrm{b}}$ & 0 \\
\hline Boiling Water & $5.00^{\mathrm{c}}$ & $32.33^{\mathrm{d}}$ & $11.33^{\mathrm{c}}$ & 0 \\
\hline Well Water & $3.67^{\mathrm{ab}}$ & $27.00^{\mathrm{c}}$ & $8.33^{\mathrm{b}}$ & 0 \\
\hline SEM & 0.55 & 1.52 & 0.78 & 0 \\
\hline P & 0.0013 & $<.0001$ & 0.0002 & 0 \\
\hline
\end{tabular}

Numbers with different superscripts are significantly different at $\mathrm{P}<0.05$

The results of the water tests showed that the water wells used around Herat is the most hardness and harmful compounds such as nitrate and Followed by municipal tap water that has the same problems. The government should take necessary measures in this case

\section{Analysis of fresh fruit}

Table 1.Amount of mineral and glucose fruit Available in Herat City, Afghanistan

\begin{tabular}{|l|l|l|l|l|l|l|l|l|l|l|}
\hline Sample & $\begin{array}{l}\text { Apple } \\
\text { (Herat) }\end{array}$ & $\begin{array}{l}\text { Apple } \\
\text { (Iran) }\end{array}$ & $\begin{array}{l}\text { Apple } \\
\text { (Ghor) }\end{array}$ & $\begin{array}{l}\text { Black } \\
\text { Grape }\end{array}$ & $\begin{array}{l}\text { Green } \\
\text { Grape }\end{array}$ & Grape & Pomegranate & Fig & SEM & P \\
\hline Refractometer & $12.60 \mathrm{e}$ & $16.80 \mathrm{~cd}$ & $10.00 \mathrm{e}$ & $17.60 \mathrm{bcd}$ & $19.20 \mathrm{bc}$ & $24.00 \mathrm{a}$ & $15.4 \mathrm{~d}$ & $19.80 \mathrm{~b}$ & 1.17 & $<.0001$ \\
\hline
\end{tabular}

Numbers with different superscripts are significantly different at $\mathrm{P}<0.05$

Table 2.Hardness result of fruit Available in Herat City, Afghanistan

\begin{tabular}{|l|l|l|l|l|l|}
\hline Sample & Apple (Herat) & Apple (Iran) & Apple (Ghor) & SEM & P \\
\hline Penetrometer & $3.23 \mathrm{~b}$ & $5.33 \mathrm{a}$ & $2.70 \mathrm{~b}$ & 0.37 & 0.0052 \\
\hline
\end{tabular}

Numbers with different superscripts are significantly different at $\mathrm{P}<0.05$

The percentage of mineral and glucose of Black Herati Grape is so high, and Iranian green apple, Herati apple and Apple (Ghor) in run has the first, second and third grade from mineral and glucose.

The Hardness result (shows the puberty of a fruit) we just test apple, and in base of grade: first Irani apple, second Herati apple and third is Apple (Ghor).

\section{Sausage and Tuna Analysis}

Table 1.Percentage of bacterial concentrations at Sausage and Tuna samples above the maximum contamination level

\begin{tabular}{|l|l|l|l|}
\hline Samples & Coliforms (\%) & APC (\%) & \\
\hline Internal & $1.67^{\mathrm{a}}$ & $1.67^{\mathrm{a}}$ & \\
\hline External & $2.33^{\mathrm{a}}$ & $2.67^{\mathrm{a}}$ & \\
\hline SEM & 0.33 & 0.33 & \\
\hline P & 0.2302 & 0.1012 & \\
\hline
\end{tabular}

Numbers with different superscripts are significantly different at $\mathrm{P}<0.05$

Unfortunately there is a high number of total bacteria in Sausage and tuna and a low number of Coliforms in these products. Which shows that some manufacturers and sellers of these products does not meet health issues both during production and during storage and lacks precision.(Sillankorva, 2012[9])

\section{Reference}

[1] Mitchell, Deborah. Safe foods: the A-to-Z guide to the most wholesome foods for you and your family. Penguin. ISBN 978-1-10121015-4. 2004, 15.

[2] Kirkland D, Kasper P, Müller L, Corvi R, Speit G. Recommended lists of genotoxic and non-genotoxic chemicals for assessment of the performance of new or improved genotoxicity tests: A follow-up to an ECVAM workshop, Mutat. Res. 653, 2008, 99-108.

[3] Bender, A, E. Food Processing and Nutrition. Academic Press. London. 1987. 
[4] Albanese, A. Newer methods of nutritional biochemistry. New York. 1976.

[5] Shiklomanov, I. A. Appraisal and Assessment of World Water Resources. Water International. International Water Resources Association. 2000, 11-32.

[6] Frazier, W.C .Food Microbiology. MC Graw Hillco. 1987.

[7] Food hygiene standards. Parliamentary Office of Science and Technology. 2009

[8] Refrigeration and Food Safety. United States Department of Agriculture, Food Safety and Inspection Service. 2010.

[9] Sillankorva, Sanna M.; Oliveira, Hugo; Azeredo, Joana. Bacteriophages and Their Role in Food Safety. International Journal of Microbiology. 2012, 1-13. 